\title{
History, applications, methodological issues and perspectives for the use of environmental DNA (eDNA) in marine and freshwater environments
}

\author{
Edgardo E. Díaz-Ferguson ${ }^{1,2}$ \& Gregory R. Moyer $^{2}$ \\ 1. Department of Fisheries and Allied Aquacultures, Auburn University, 203 Swingle Hall, Auburn, Alabama; \\ edgardo_diaz-ferguson@fws.gov \\ 2. U.S. Fish and Wildlife Service, Fish Technology Center, Conservation Genetics Lab, 5151 Spring Street, Warm \\ Springs, Georgia 31830; greg_moyer@fws.gov
}

\author{
Received 30-I-2014. Corrected 08-V-2014. Accepted 10-VI-2014.
}

\begin{abstract}
Genetic material (short DNA fragments) left behind by species in nonliving components of the environment (e.g. soil, sediment, or water) is defined as environmental DNA (eDNA). This DNA has been previously described as particulate DNA and has been used to detect and describe microbial communities in marine sediments since the mid-1980's and phytoplankton communities in the water column since the early-1990's. More recently, eDNA has been used to monitor invasive or endangered vertebrate and invertebrate species. While there is a steady increase in the applicability of eDNA as a monitoring tool, a variety of eDNA applications are emerging in fields such as forensics, population and community ecology, and taxonomy. This review provides scientist with an understanding of the methods underlying eDNA detection as well as applications, key methodological considerations, and emerging areas of interest for its use in ecology and conservation of freshwater and marine environments. Rev. Biol. Trop. 62 (4): 1273-1284. Epub 2014 December 01.
\end{abstract}

Key words: environmental DNA (eDNA), detection probability, occupancy models, persistence, metabarcode, minibarcode.

In order to understand distributions, patterns, and abundances for populations or species, the collection (detection) and identification of individuals from their physical origins must be undertaken. Thus, species detection is fundamental to scientific disciplines such as phylogenetics, conservation biology, and ecology. However, species detection is sometimes extremely difficult especially in marine and aquatic environments where organisms have complex life cycles, and direct observation of early development stages is almost impossible (Ficetola, Miaud, Pompanon, \& Taberlet, 2008). Species detection in these environments has been conducted using traditional direct observation methods (visual or acoustic) (Thomsen et al., 2012a). Nonetheless, traditional detection methods can have logistic limitations, be time consuming, expensive, and in some cases, harmful to the environment (e.g., marine bottom trawls, electrofishing and rotenone poisoning) (Thomsen et al., 2012b). The advent of novel molecular and forensic methods have provided innovative tools for detecting marine and aquatic organisms that may circumvent the aforementioned limitations (Darling \& Blum, 2007; Valentini, Pompano, \& Taberlet, 2009; Lodge et al., 2012).

One such tool is the detection of an organism's environmental DNA (eDNA). Defined as short DNA fragments that an organism leaves behind in non-living components of the ecosystem (i.e., water, air or sediments), eDNA is derived from either cellular DNA present in epithelial cells released by organisms to the environment through skin, urine, feces or mucus or extracellular DNA that is the DNA in the environment resulting from cell 
death and subsequent destruction of cell structure (Foote, Thomsen, Sveegaard, Wahlberg, Kielgast, Kyhn, Salling, Galatius, Orlando, \& Gilbert, 2012; Taberlet, Coissac, Hajibabaei, \& Rieseberg, 2012a). Methodologically, eDNA detection requires the development of genetic markers specific to that target taxon or taxa. Once genetic markers are developed, target eDNA fragments can be detected using different molecular methods including traditional or End-Point PCR, and visualization of the PCR product through electrophoresis, quantitative or Real Time PCR (qPCR), Sanger sequencing or more recent Next-generation DNA sequencing (Taberlet, Coissac, Pompanon, Brochman, \& Willerslev, 2012b; Yoccoz, 2012). Method selection is related to the research or management question, sampling logistics, life history of the species, and availability of funds.

This review provides a summary of the methods, history, current applications, and future areas of interest for eDNA as well as areas of concern and uncertainty for its use in marine and freshwater ecosystems.

\section{History of eDNA}

Although perceived as a modern method, eDNA has been utilized since the mid-1980's for the detection of bacterial communities in marine sediments (Ogram, Sayler, \& Barkay, 1987). In the 1990's, eDNA methods were employed to monitor phytoplankton blooms and assess changes in biomass of bacterial communities (Bailiff \& Karl 1991; Weirbauer, Fucks, \& Peduzzi, 1993; Paul, Kellog, \& Jiang, 1996). During this time period eDNA classification was dependent on particulate size (Paul et al., 1996). Thus, eDNA found in aggregates greater than $0.2 \mu \mathrm{m}$ associated with cells (e.g., microbial eDNA) was termed particulate DNA or P-DNA while eDNA less than this size (e.g., dissolved viral DNA) was considered dissolved DNA or D-DNA (Paul et al., 1996).

Environmental DNA is considered a similar molecular identification tool as DNA barcoding (i.e., a $650 \mathrm{bp}$ sequence of the mtDNA COI gene used for the identification of vertebrates and invertebrates) with the sole difference being that eDNA fragments are usually smaller (100bp or less) and other genes besides COI are used. Because of these similarities, some authors refer to eDNA detection as minibarcode detection (Hajibabaei, Singer, Clare, Hebert, 2007; Baird \& Hajibabaei, 2012). In contrast, microbiologists refer to the analysis of the whole bacterial communities in an ecosystem obtained from water, sediments or soil samples as metagenomics (Handelsman, 2004).

More recently, the use of eDNA has gained attention for eukaryote detection to assess sources of fecal contamination in aquatic systems (Layton, 2006). Yet, it was not until 2008, that French researchers first applied eDNA methods to confirm the presence of an aquatic invasive species (Rana catesbiana) from water samples in a natural lotic system (Ficetola et al., 2008). In North America, Jerde, Mahon, Chadderton \& Lodge (2011) demonstrated the efficacy of eDNA as a detection tool for invasive species in freshwater systems. This study focused on the detection of silver and bighead Asian carp (Hypophthalmichthys molitrix and H. nobilis). The first study to apply eDNA as a detection tool for federally endangered organisms was also published in 2011 (Goldberg, Pilliod, Arkle, \& Waits, 2011). In this study researchers explored the effect of seasonality on eDNA detection of amphibians. Also in 2011, the first study on eDNA persistence of amphibian species inhabiting freshwater ecosystems was published by Dejean, Valentini, Duparc, Pellier-Cuit, Pompanon, Taberlet, \& Miaud, (2011).

The first uses of eDNA detection in the marine environment was conducted by Foote et al. (2012a) for genetic monitoring of marine mammals and by Thomsen et al., (2012b) to estimate marine fish biodiverstiy. The first reviews of eDNA also came in 2012 (Taberlet et al., 2012a; Yaccoz, 2012). Methodological papers trying to make approximations between fish biomass, abundance and eDNA detection probability were also published during the same time period by Dejean et al. (2011) and Takahara, Minamoto, Yamanaka, Hideyuki \& 
Kawabata (2012). Recently, studies have been focused on modeling persistence and detection using multiple biotic and abiotic factors such as vectors, system volume, sample volume, eDNA dynamics, stream flow, discharge and particle size (Piaggio, Engeman, Hopken, Humphrey, Keacher, Bruce, \& Michael, 2013; Schmidt, Kery, Ursenbasher, Hyman, \& Collins, 2013; Barnes, Turner, Jerde, Renshaw, Chadderton, \& Lodge, 2014; Pilliod, Goldberg, Arkle, \& Waits, 2014; Turner, Barnes, Charles, Jones, Xu, Jerde, \& Lodge, 2014).

\section{eDNA applications in ecology and conservation}

Multiple applications of eDNA exist for use in the fields of marine ecology and conservation biology, and include wildlife DNA forensics, detection of cryptic and endangered species/populations, detection of aquatic invasive species (AIS), biodiversity and community assessment, population dynamics, ecosystem health, trophic interactions, dietary studies, and species historical patterns of distribution. Below is a brief synopsis of each of these applications.

1. Wildlife DNA forensics: The field of wildlife DNA forensics, which is a synthesis of conservation genetics and forensic genetics, was developed to address the increasing need of DNA forensic tools in wildlife law enforcement (Ogden, 2008, 2009). The applicability of eDNA as a forensic tool appears promising to address basic forensic identification issues at the level of individual (e.g., hatchery vs wild origin, location of origin, species introduction), population, or species. Detection of eDNA fragments can also provide evidence for illegal wildlife trade and traceability of illegal fishing products (e.g., shark or rayfins).

2. Detection of low density populations: The detection of eDNA for species or populations that are at low densities (e.g., threatened or endangered taxa) or are visually evasive (e.g., madtom catfishes) appears promising (Goldberg et al., 2011; Takahara et al., 2012; Takahara, Minamoto \& Doi, 2013). For example, the chucky madtom (Noturus crypticus), a United States federally endangered species, was last observed in 2004 despite intensive, survey efforts using traditional sampling methods (i.e., seines and snorkel surveys). The increased sensitivity of eDNA over traditional sampling methods may assist in the detection of this species; alternatively, the lack of detection could prompt a federal status determination for this species as presumed extinct. However, caution should be taken when using the lack of eDNA detection as a means to determine a taxon's conservation status because the probability of eDNA detection will vary depending on the volume of water sampled and the presumed (but usually unknown) density of the target organism in the field. The development of sampling protocols that address eDNA detection probabilities will be critical for determining the conservation status of a species in the future.

3. Detection of aquatic invasive species (AIS): The use of molecular methods to detect AIS has proliferated in recent years. The development of molecular markers specific to the target species provides a new tool for conservation managers that seek to monitor AIS. Thus, the use of eDNA provides the possibility of confirming AIS detection in hours or days instead of weeks or months, allowing managers to act quickly to minimize dispersal and settlement of the invader (Darling \& Mahon, 2011). In addition, eDNA detection of AIS provides clues to determine origin of the introduction and possible routes of invasion.

4. Biodiversity and community structure: The term DNA metabarcoding is used to designate multispecies identification using eDNA samples (Taberlet et al., 2012b). The approach relies on Next-generation sequencing (permitting the sequencing of billions of 100 base pair reads) and the creation of taxonomic reference libraries 
(e.g., the Barcode of Life). Thus instead of identifying one species from a single water sample, an eDNA metabarcoding approach has the potential to identify the eDNA of any taxon collected in a water sample given that the DNA sequences are already deposited in a repository. Thus, metabarcoding can be used as a tool to produce biodiversity estimates that are taxonomically comprehensive, quicker to produce, and less reliant on taxonomic expertise ( $\mathrm{Ji}$ et al., 2013).

5. Population dynamics: Detection and quantification of eDNA can be used as a reference or indirect measurement of population attributes such as abundance, distribution, and biomass. Distributions of organisms and biomass in freshwater systems have been correlated with eDNA concentration (Takahara et al., 2012, 2013). Thus eDNA concentration has been used as a proxy for population distribution in amphibians (Ficetola et al., 2008; Goldberg et al., 2011), fishes (Mahon, Jerde, Galaska, Bergner, Chadderton, Lodge, Hunter, \& Nico, 2012; Minamoto, Yamanaka, Takahara, Honjo, \& Kawabata, 2012) and reptiles species (Piaggio et al., 2013). In marine species no studies have been conducted to determine the relationship between eDNA concentration and species distribution, abundance and biomass. However, spatial and temporal oscillations of bacterial and phytoplankton communities have been correlated with DNA concentration in coastal waters during blooming events (Bailiff \& Karl, 1991).

6. Ecosystem health: Presence of AIS as well as introduced pathogens (viral or fungal) can have severe demographic and genetic impacts to existing native populations (Blanc, 2001). By using eDNA to monitor virus concentration (Minamoto, Honjo, \& Kawabata, 2009) or invasive species, managers can indirectly monitor for ecosystem health. In addition, the use of eDNA to monitor changes in community composition and reductions in species diversity can also serve as a proxy for assessing ecosystem health. More specifically, changes in species diversity can influence overall ecosystem dynamics directly or indirectly, by reducing water quality (Strayer, 2010), changing nutrient dynamics (Didham, Tylianakis, Hutchinson, Ewers, \& Gemmel, 2005) or affecting the distribution of submerged machrophytes (Strayer, 2010). Therefore, eDNA could be a useful tool for future risk-based decision making of natural resources (Wilson \& Wright, 2013) or environmental impact assessments (Veldhoen, Ikonomou, \& Helbing, 2012).

7. Trophic interactions and dietary studies: Traditional studies allow quantifying and estimating the relationship between predator and prey as well as herbivore and plant relationships using stomach contents, feces, or fecal pellets. The direct observation or identification of the prey in the stomach or in the fecal material often is difficult and can reduce the taxonomic resolution or introduce bias (Braley, Goldsworthy, Page, Steer, \& Austin, 2010). Thus, the use of eDNA fragments or metabarcoding approach using stomach contents as target DNA can be used for dietary and trophic studies without the observation or identification of the prey in the stomach or feces (Zarzoso-Lacoste, Corse, \& Vidal, 2013).

8. Species historical patterns of distribution: Short DNA sequences can persist for long time periods mainly in cold environments with reduced exposure or absence of light (Willerslev et al. 2003). This has been observed in studies conducted in old sediments and ice cores (Hofreiter, Mead, Martin, \& Poinar, 2003; Willerslev, Capellini, Boomsman, \& Nielsen, 2007). Thus, genetic information (ancient eDNA) in sediments, ice cores and other environmental sources could allow scientists to reconstruct community structure and historical ecological process. 


\section{eDNA persistence}

DNA persistence can be defined as the continuance of DNA fragments once the source of this DNA is removed from the system (Dejean et al. 2011). Once extracellular DNA is released in the environment, it may persist, be absorbed in organic and inorganic particles, be degraded, or transformed by microorganisms. Persistence is strongly correlated with species density, body size and the ratio between amounts of released/degraded DNA by species into the environment. In control conditions, DNA detection decreases with time once the source of DNA is removed from the environment (Dejean et al., 2011). Persistence values vary across taxa and life history i.e., changes in size, behavior and stage of development can affect the amount of DNA available at a local scale (Thomsen et al. 2012a).

Persistence estimates have been determined for different taxonomic groups: from 15 to 30 days for fresh water fishes (Dejean et al., 2011 \& Takahara et al., 2012a), 15 to 30 days for amphibians (Ficetola et al., 2008; Goldberg et al., 2011), 0.9 to 7 days for marine mammals (Foote et al., 2012), 21 days for mudsnails (Goldberg, Sepulveda, Ray, Baumgardt, \& Waits, 2013), and 14 days for reptiles (Piaggio et al., 2013). In addition to density, size and life history features of the target taxa, eDNA persistence can be influenced by other biotic factors such as bacterial and fungal concentrations (Dejean et al., 2011). The role of abiotic factors on eDNA persistence has also been reported (e.g., oxygen concentration, nuclease activity, $\mathrm{pH}$, conductivity, UV radiation, $\mathrm{pH}$ and temperature) (Shapiro, 2008; Dejean et al. 2011; Barnes et al., 2014). Nonetheless, the effect of these factors has been studied independently and only one of these studies had measured how covariation of these factors (specific environmental conditions) affects persistence (Barnes et al., 2014). Other abiotic factors related to the system that can also affect persistence include: stream flow, currents, tidal oscillations, type of sediment, and salinity (Corinaldesi, Beolchini, \& Dell'Anno, 2008;
Golberg et al., 2011; Barnes et al., 2014). For example, eDNA persistence in freshwater lentic systems has been shown to be as great as 30 days (Ficetola et al., 2008) while for marine systems (open and highly dynamic systems) it only averages approximately seven days (Foote et al., 2012; Thomsen et al., 2012b).

Fragment size of target eDNA is also important when persistence is analyzed. It has been shown that fragments within a range of $300-400$ bp can persist in the aquatic environment for at least a week in controlled conditions (Alvarez, Yumet, Santiago, \& Torantos, 1996; Zhu, 2006). In contrast, shorter fragments of DNA (100bp or less) have been known to remain stable after several weeks and even years depending on environmental conditions (Willlerslev et al., 2003, 2007; Taberlet et al., 2012a).

\section{Freshwater vs marine systems}

Freshwater and marine ecosystems constitute great reservoirs of eDNA. For both, eDNA detection is correlated with abundance of the target species and the rate by which DNA is released and degraded by biotic and abiotic factors (Thomsen et al., 2012a, b). In freshwater systems, eDNA is usually homogeneously distributed and the successful use of this technology has been proven in a number of studies comprising a range of taxa (Lodge et al., 2012; Thomsen et al., 2012a). For marine systems, the detection of eDNA is possible but less reliable than in freshwater systems (Foote et al. 2012; Jones, 2013). Despite the high density of marine biota, the vast volume of sea water in relation to biomass promotes eDNA dilution and dispersion. This compounded by the dynamic nature of marine environments (e.g., strong tides, current system and oceanographic events) and the increased inhibition of subsequent molecular procedures due to the high salinity environments, make eDNA detection more challenging when compared to freshwater systems. Currently, eDNA studies conducted in the marine environment are limited to detection of fishes, marine mammals and microbial 
communities in temperate areas (Venter et al. 2004; Foote et al. 2012; Thomsen et al. 2012b; Kelly, Port, Yamahara, \& Crowder, 2013). Despite of the success on eDNA detection of these taxa in the marine systems; scientists have to consider that eDNA degrades rapidly in seawater (less than seven days) and detection of marine species is considered to be local (Thomsen et al. 2012b). Therefore, the use of eDNA in marine systems is still a challenge, especially in applications such as the establishment of relationships between distribution, abundance, or biomass of species with eDNA detection probabilities, since dilution and dispersion of eDNA is greater.

In addition to the aforementioned issues, marine and freshwater tropical environments have high surface temperatures (sometimes above $30^{\circ} \mathrm{C}$ ) and elevated UV radiation at sea level that may increase eDNA degradation rate and reduce the persistence period in the water, decreasing the detection probability (Barnes et al., 2014). For this reason the selection of the appropriate detection method, preliminary laboratory and aquarium eDNA assays and consideration of species size, vertical distribution, current or water flow, life history and degradation rates among different environments, are required before the beginning of any field detection protocol (Kelly et al., 2013).

\section{eDNA considerations for experimental design}

Successful eDNA detection of eukaryotes in freshwater and marine ecosystems relies on accuracy of the experimental design in accordance with the environment, life history, and behavior of the target species. Therefore the following topics along with clearly defined hypotheses should be considered/articulated before the method is applied to a natural system.

Life history considerations: Seasonal changes in behavior including spawning migrations, period of larval development, phylopatry, vertical movements and tidal oscillations can influence eDNA concentration as well as temporal and spatial distributions of
eDNA fragments; therefore, depending on the research question, it may be necessary to incorporate information regarding the life history of the organism in to the experimental design. For example, during spawning events, there is a release of multiple sources of genetic material into the environment including blood, urine, fecal material, epithelial cells and gametes. Taking advantage of this information may allow a better detection of the species; alternatively, it could also overestimate the presence of a species in a particular period.

Demographic connectivity patterns: Movement of organisms is a measurement of marine and freshwater connectivity and implies movement of genetic material. Therefore, the presence of eDNA from a particular species between geographically or oceanographically connected areas could be a sign of population connectivity. Understanding connectivity is essential for the establishment of population boundaries, marine corridors and common protected areas (Díaz-Ferguson, Haney, Wares, \& Silliman, 2010; Díaz-Ferguson, 2012).

Taxa and animal size: Based on freshwater studies (mainly focused in fishes and amphibians) the greater the size of the individual, the more likely it is to be detected because of the increased amount of eDNA input into the system. The eDNA of invertebrates is less likely to be detected than in vertebrates due to the presence of an exoskeleton (Golberg et al., 2013). However, high detection probabilities have been found for freshwater tadpole shrimp (Lepidurus apus) and the New Zealand mudsnail (Potamopyrgus antipodarum) (Goldberg et al., 2013). Note that depending on the taxon, exoskeletons are often shed at known times of the year; thus making them a potential source of eDNA.

Vectors: eDNA can be transported by alternative pathways or introduced into a system not only because the target species inhabits the system but by other means (Darling \& Mahon, 2011). Vectors are often problematic for many eDNA applications, because while the eDNA is detected in the area, the taxon of interest is not actually there, creating a false positive. 
The following are the most common vectors of DNA in freshwater and marine systems:

1. Animals: Introduction of DNA by animal vectors is mainly driven by birds in natural ecosystems. However, any predator can transport eDNA from other species via defecation or prey transport.

2. Water contamination: Input of water from external sources can also be an alternative pathway to introduce eDNA into a system. Discharge of ballast water from ships has the potential to harbor eDNA because vessels often take on ballast water from coastal areas rich in biodiversity and transport species or DNA to other areas where these species DNA have not been reported (Rothlisberger \& Lodge, 2013). In addition, accidental input of water from the aquaculture industry can also cause introduction of exogenous DNA into a natural system.

\section{Perspective and future of eDNA}

The perspective and future of eDNA as a method species detection method and subsequent applications will focus on three general areas as follows: resolving eDNA methodological issues, improving eDNA technologies, and exploring new of eDNA applications. Below we discuss upon each of these areas.

Resolving eDNA methodological issues: Future success of eDNA as an effective tool for species detection will rely on resolving eDNA issues related to the optimization of molecular assays and confirmation of positive samples. Optimization of eDNA molecular assays involves testing for sensitivity (i.e., using known amounts of DNA from the target species in order to determine the minimum amount of target DNA required for detection), specificity (i.e., conducting cross species amplification to make sure that the assay only detect the presence of the species of interest), and utilization of strict field and laboratory standards and controls (Dejean, Valentini, Miguel, Taberlet, Belleman, \& Miaud, 2012; Wilcox, McKelvey,
Young, Jane, Lowe, Whiteley, \& Schwartz, 2013). In doing so, researchers minimize the detection of false positives. Another method to limit the uncertainty associated with eDNA false positives, is to confirm the identity of all positive eDNA via Sanger sequencing (Darling \& Mahon, 2011).

False negatives are also a concern for eDNA detection. Although false negatives will always be a possibility due to the myriad array of abiotic and biotic factors affecting eDNA persistence, there are several steps that can be incorporated into an experimental design to minimize eDNA false negatives. The detection of eDNA is contingent on PCR; thus any inhibition of the PCR reaction, if not accounted for, will lead to false negatives. Leading causes of PCR inhibition include high salinity in marine systems (Foote et al., 2012) and humic/fluvic acids, tannins and polyphenols in freshwater environments (Matheson, Gurney, Esau, \& Lehto, 2010). Thus, a DNA extraction kit that removes potential inhibitors is recommended along with appropriate PCR controls (Piaggio et al. 2013). Specifically for marine environments eDNA detection is considered to be local due to the reduced persistence period (Foote et al., 2012; Thomsen et al. 2012b). This fact makes marine environments prone to high false -negative detection rates. Therefore, future eDNA studies focused on marine ecosystems should consider preliminary laboratory assays that test the effect of the ecosystem dynamics on eDNA distribution (i.e., particle size dynamics, influence of local currents, advection transport and salinity gradients) (Turner et al., 2014), and the impact of this dynamic on false negative rates.

Furthermore, eDNA, like most if not all traditional sampling methods, suffers from imperfect detection (Schmidt et al. 2013). Therefore, the incorporation of occupancy models (see below) in an eDNA experimental design will allow researchers to evaluate and quantify the false-negative measurement error in freshwater and marine ecosystems (Mordecai, Mattsson, Tzilkowski, \& Cooper, 2011). The same models can also account for eDNA 
false positives (Miller, Talley, Lips, \& Campbell Grant, 2012).

Improving supporting eDNA technologies: The use of eDNA as a detection tool is generating an increasing amount of genetic information associated to spatial and temporal variables (i.e., annual data by season, site and region). This fact will be a computational challenge for scientists in the near future. Therefore it will be necessary to increase data base size, improve data management, and create archival eDNA data bases (Yaccoz, 2012). For instance, the collection of water samples and the DNA extracted from those samples is an important reference to assess future spatial distribution of species, and monitor biodiversity and community structure.

Statistical analyses: Sampling methods that rely on presence/absence data to estimate the number of individuals in an area, often suffer from imperfect detection (Pollock, Nichols, Simmons, Farnworth, Bailye, \& Sauer, 2002); and eDNA studies will too (Schmidt et al. 2013). To date, there has been little attention given to eDNA detection probabilities with most studies assuming perfect or near perfect detection of the taxon of interest (Hyman \& Collins, 2012; Thomsen et al., 2012a). Meanwhile biotic and abiotic factors influencing eDNA are beginning to be understood (MacKensie et al., 2002; MacKensie, Nichols, Royle, Pollock, \& Hines, 2006). However, how these parameters might affect eDNA detection probabilities, remains unclear (Pilliod et al., 2014). Site occupancy models provide a means to account for imperfect detection of various sampling methods (Pollock et al., 2002; Andrew Royle, \& Dorazio, 2008; Pilliod, Goldberg, Arkle, \& Waits, 2013) including eDNA methods (Schmidt et al., 2013). Occupancy models can be used to study the effects of various abiotic and biotic factors that influence detection probabilities (both in the field and in the laboratory), and to determine the number of visits, number of samples and volume of water needed to be confident that a species is absent from a site (Schmidt et al., 2013). The latter will be particularly important for determining the conservation status of many threatened and endangered organisms.

New frontiers and eDNA applications: Emerging areas of interest for eDNA methods include areas where traditional sampling methodologies remain unfeasible such as underwater plains on the deep ocean floor (i.e., abyssal plains especially hadopelagic zones). The community composition in these deep ocean environments still remains relatively unknown, primarily because studies pertaining to hadal ecosystems are rare (Bull, Stach, Ward, \& Goodfellow, 2005). Another emerging area of eDNA interest is using the method to assess specific biological events such as spawning, settlement, and recruitment using fluctuations on target eDNA concentration when and where a particular life history event has occurred. This may be of importance when predicting the structure and dynamics of marine communities from the environmental conditions they experience, because of abundance, biomass or productivity changes, and theoretically should the amount of eDNA that may be detected. For example, eDNA detection methods may someday serve as tools to elucidate the processes that structure phytoplankton communities, which is of importance to assessing impacts of climate change on ecosystem function (Eggers, Lewandowska, Ramos, Blanco-Ameijeiras, Gallo, \& Mathiesen, 2013), trophic dynamics (Sterner \& Elser, 2002), and water quality (Anderson, Cembella, \& Hallegraeff 1998).

In summary, the detection of trace amounts of DNA in environmental samples is well established in the field of microbiology, but this technique has only recently garnered applicability in conservation biology and ecology particularly for the detection of aquatic invasive species or endangered organisms, and inventory and monitoring. While eDNA applications appear promising, the detection of eDNA from freshwater and marine ecosystems will depend on clearly articulated hypotheses and proper experimental design, in both the laboratory and field, to adequately address these hypotheses (i.e., laboratory studies should seek minimize false positives and negatives and field studies 
should address imperfect detection) Finally, the use of eDNA to detect an organism is simply another tool to be used by biologists; thus, results should be corroborated with other detection techniques, especially when the research has conservation and management implications (i.e., presence/absence of endangered organisms or invasive species). As DNA barcoding moves to become a global standard for species identification (Bucklin, Steinke \& BlancoBernal, 2011; Shen, Chen, \& Murphy, 2013), eDNA, as a detection method, it is poised to be a potentially reliable, cost effective and expeditious tool for the inventory and monitoring of species, and the estimation of biodiversity and community structure in freshwater ecosystems. In marine ecosystems more research is needed in order to avoid false negatives, considering the reduced persistence of eDNA on these environments, that limits detection probability to a local scale.

\section{ACKNOWLEDGMENTS}

We want to thank the Fish and Wildlife Service and the AIS inventory and monitoring program for funding our research. We also want to thank Fred Utter and Jorge Cortés for providing feedback and comments to this review.

\section{RESUMEN}

Historia, aplicaciones, aspectos metodológicos y perspectivas para el uso del ADN ambiental (ADNa) en ecosistemas marinos y de agua dulce. El material genético que liberan los organismos en los componentes no vivos del ecosistema (aire, suelo, agua y sedimentos) recibe el nombre de ADN ambiental (ADNa) (eDNA, por su nombre en inglés). Este ADN previamente definido como ADN particulado ha sido utilizado desde mediados de la década de los ochenta y principios de los noventas para describir la composición de las comunidades microbianas en sedimentos marinos y de comunidades microbianas y fitoplanctónicas en la columna de agua. Recientemente el ADNa es utilizado principalmente para la detección y monitoreo de especies invasoras y en peligro. No obstante, existen múltiples áreas en las que este método puede ser utilizado como por ejemplo en ciencias forenses, ecología de poblaciones y comunidades, y taxonomía. Esta revisión proporciona información sobre esta nueva herramienta molecular, sus actuales y futuras aplicaciones, historia, principales consideraciones metodológicas y áreas emergentes para su uso en ecología y conservación de ambientes marinos y de agua dulce.

Palabras clave: ADN ambiental (ADNa), probabilidad de detección, modelos de ocupación, persistencia, meta código de barras, mini código de barras.

\section{REFERENCES}

Alvarez, A. J., Yumet, G., Santiago, C., \& Torantos, G. (1996). Stability of manipulated plasmid DNA in aquatic environments. Environmental Toxicology and Water Quality, 11, 129-135.

Anderson, D. M., Cembella, A. D., \& Hallegraeff, G. M. (Eds.) (1998). The Physiological Ecology of Harmful Algal Blooms. Heidelberg: Springer-Verlag.

Andrew Royle, J. \& Dorazio, R. (2008). Hierarchical modeling and inference in ecology: the analysis of data from populations, metapopulations and communities. Oxford, UK: Elsevier.

Bailiff, M. \& Karl, D. (1991). Dissolved and particulate DNA dynamics during a spring bloom in the Antartic Peninsula region, 1986-1987. Deep Sea Research. Part 1. Oceanographic Research, 38(8-9), 1077-1095.

Baird, D. \& Hajibabaei, M. (2012). Biomonitoring 2.0 a new paradigm in ecosystem assessment made possible by next generation DNA sequencing. Molecular Ecology, 21, 2039-2044.

Barnes, M. A., Turner, C. R., Jerde, C. L., Renshaw, M. A., Lindsay Chadderton, W., \& Lodge, D. (2014). Environmental conditions influence eDNA persistence in aquatic systems. Environmental Science and Technology, 48, 1819-1827.

Blanc, G. (2001). Introduction of pathogens in European aquatic ecosystems: attempt of evaluation and realities. In A. Uriarte \& B. Basurco (pp. 37-50) (Eds.). Environmental Impact Assessment of Mediterranean Aquaculture Farms.

Braley, M., Goldsworthy, S., Page, B., Steer, M., \& Austin, J. (2010). Assessing morphological and DNA-based diet analysis techniques in a generalist predator, the arrow squid Nototodarus studies gouldi. Molecular Ecology Research, 10(3), 466-474.

Bucklin, A., Steinke, D., \& Blanco-Bernal, L. (2011). DNA barcoding of marine metazoa. Annuals Reviews in Marine Science, 3, 471-508.

Bull, A., Stach, J., Ward, A., \& Goodfellow, M. (2005). Marine actinobacteria: perspectives, challenges, future directions. Antonie van Leeuwenhock, 87(3), 65-79.

Corinaldesi, C., Beolchini, F., \& Dell'Anno, A. (2008). Damage and degradation rates of extracellular DNA 
in sediments: implications for the preservation of gene sequences. Molecular Ecology, 17, 3939-3951.

Darling, J., \& Blum, M. (2007). DNA-based methods for monitoring invasive species: a review and prospectus. Biological Invasions, 9, 751-765.

Darling, J. \& Mahon, A. (2012). From molecules to management: Adopting DNA based methods for monitoring biological invasions in aquatic environments. Environmental Research, 111(7), 978-988.

Dejean, T., Valentini, A., Duparc, A., Pellier-Cuit, S., Pompanon, F., Taberlet, P., \& Miaud, C. (2011). Persistence of environmental DNA in freshwater ecosystems. PLoS ONE, 6 (8), e23398.

Dejean, T., Valentini, A., Miquel, C., Taberlet, P., Bellemain, E., \& Miaud, C. (2012). Improved detection of an alien invasive species through environmental DNA barcoding: the example of the American bullfrog Lithobates cathesbeianus. Journal of Applied Ecology, 49, 953-959.

Díaz-Ferguson, E., Haney, R., Wares, J., \& Silliman, B. (2010). Populations genetics of a trochid gastropod broadens picture of Caribbean Sea connectivity. PLoS ONE, 5(9), e12675.

Díaz-Ferguson, E. (2012). Introducción a la ecología molecular marina: aplicaciones y perspectivas. Via Argentina, Panamá, República de Panamá. Universal Books. 212p.

Didham, R., Tylianakis, J., Hutchinson, M., Ewers, R., \& Gemmel, N. (2005). Are invasive species the drivers of ecological change. Trends in Ecology and Evolution, 20(9), 470-474.

Eggers, S., Lewandowska, A., Ramos, B., Blanco-Ameijeiras, J., Gallo, F., \& Mathiesen, B. (2013). Community composition has greater impact on the functioning of marine phytoplankton communities than ocean acidification. Global Change Biology, doi: 10.1111qcb. 12421

Ficetola, F., Miaud, C., Pompanon, F., \& Taberlet, P. (2008). Species detection using environmental DNA from water samples. Biological Letters, 4, 423-425.

Foote, A., Thomsen, P., Sveegaard, S., Wahlberg, M., Kielgast, J., Kyhn, L., Salling, A., Galatius, A., Orlando, L., Thomas, M., \& Gilbert, T. (2012). Investigating the potential use of environmental DNA (eDNA) for genetic monitoring of marine mammals. PLOS ONE, 7 (8), e4178.

Goldberg, C., Pillod, D., Arkle, R., \& Waits, L. (2011). Molecular detection of vertebrates in stream water: a demonstration using rocky mountain tailed frogs and Idaho giant Salamanders. PLoS ONE, 6(7), e22746.

Goldberg, C., Sepulveda, A., Ray, A., Baumgardt, J., \& Waits, L. (2013). Environmental DNA as a new method for early detection of New Zealand mudsnails
(Potamopyrgus antipodarum). Freshwater Science, 32 (3), 792-800.

Hajibabaei, M., Singer, G., Clare, E., \& Hebert, P. (2007). Design and applicability of DNA arrays and DNA barcodes in biodiversity monitoring. BMC Biology, 5, 24-30.

Handelsman, J. (2004). Metagenomics: applications of genomics to uncultured microorganisms. Microbiology and Molecular Biology Reviews, 68, 669.

Hofreiter, M., Mead, J., Martin, P., \& Poinar, H. (2003). Molecular carving. Current Biology, 13, R693-R695.

Hyman, O. \& Collins, J. (2012). Evaluation of a filtrationbased method for detecting Batrachochytrium dedrobatidis in natural bodies of water. Diseases of Aquatic Organisms, 97 (3), 185-195.

Jerde, C., Mahon, A., Chadderton, W., \& Lodge, D. (2011). "Sight unseen" detection of rare aquatic species using environmental DNA. Conservation Letters, 4, 150-157.

Ji, Y., Ashton, L., Pedley, S., Edwards, D., Tang, Y., Nakamura, A., Kitching, R., Dolman, P., Woodcock, P., Edwards, F., Larsen, T., Hsu, W., Benedick, S., Hammer, K., Wilcove, D., Bruce, C., Wang, X., Levi, T., Lott, M., Emerson, B., \& Yu, D. W. (2013). Reliable, verifiable and efficient monitoring of biodiversity via metabarcoding. Ecology Letters, 16, 1245-1257.

Jones, M. (2013). Environmental DNA: Genetics steps forward when traditional ecological surveys fall short. Fisheries, 38(7), 332-333.

Kelly, R., Port, J., Yamahara, K., \& Crowder, L. 2013. Using environmental DNA to census marine fishes in a large mesocosm. PLoS ONE, 9(1), e86175.

Layton, A. (2006). Development of Bactereroides 16S rRNA Gene Taqman-base real time PCR assays for estimation of total, human and bovine fecal pollution in rivers. Applied Environmental Microbiology, 72(6), 4214-4224.

Lodge, D., Turner, C., Jerde, C., Barnes, M., Chadderton, L., Egan, S., Feder, J., Mahon, A., \& Pfrender, M. (2012). Conservation in a cup of water: estimating biodiversity and population abundance from environmental DNA. Molecular Ecology, 11, 2555-2558.

MacKenzie, D., Nichols, J., Lachman, G., Droege, S., Royle, J., \& Langtimm, C. (2002). Estimating site occupancy rates when detection probabilities are less than one. Ecology, 84, 2200-2207.

MacKenzie, D., Nichols, J., Royle, J., Pollock, K., \& Hines, J. (2006). Occupancy Estimation and Modeling: Inferring Patterns and Dynamics of Species Occurrence. San Diego, United States: Elsevier.

Mahon, A., Jerde, C., Galaska, M., Bergner, J., Chadderton, W., Lodge, D., Hunter, M., \& Nico, L. (2012). Validation of eDNA surveillance sensitivity for detection 
of Asian Carps in controlled and field experiments. PLOS ONE, 8(3), e58316.

Matheson, C., Gurney, C., Esau, N., \& Lehto, R. (2010). Assessing PCR inhibition from humic substances. The Open Enzyme Inhibition Journal, 3, 38-45.

Miller, D., Talley, B., Lips, K., \& Campbell Grant, E. (2012). Estimating patterns and drivers of infection prevalence and intensity when detection is imperfect and sampling error occurs. Methods in Ecology and Evolution, 3(5), 850-859.

Minamoto, T., Honjo, M., \& Kawabata, Z. (2009). Seasonal distribution of cyprinid herpes virus 3 in Lake Biwa Japan. Applied Environmental Microbiology, 75, 6900-6904.

Minamoto, T., Yamanaka, H., Takahara, T., Honjo, M., \& Kawabata, Z. (2012). Surveillance of fish species composition using environmental DNA. Limnology, 13, 193-197.

Mordecai, R., Mattsson, B., Tzilkowski, C., \& Cooper, R. (2011). Addressing challenges when studying mobile or episodic species: hierarchical Bayes estimation of occupancy and use. Journal of Applied Ecology, 48(1), 56-66.

Ogden, R. (2008). Fisheries forensics: the use of DNA tools for improving compliance, traceability and enforcement in the fishing industry. Fish and Fisheries, 9, 462-472.

Ogden, R. (2009). Wildlife DNA forensics- Bringing the gap between conservation genetics and law enforcement. Endanger Species Research, 9, 179-195.

Ogram, A., Sayler, G., \& Barkay, T. (1987). The extraction and purification of microbial DNA from sediments. Journal of Microbiological Methods, 7, 57-66.

Paul, J., Kellogg, C., \& Jiang, S. (1996). Viruses and DNA in marine environments. In R. R. Colwell (pp. 115124) (Eds.). Microbial diversity in time and space. Plenum Press, New York.

Piaggio, A., Engeman, R., Hopken, M., Humphrey, J., Keacher, K., Bruce, W., \& Michael, A. (2013). Detecting an elusive invasive species: a diagnostic PCR to detect Burmese python in Florida waters and an assessment of persistence of environmental DNA. Molecular Ecology Research, doi:101111/1755-0998.12180.

Pilliod, D., Goldberg, C., Arkle, R., \& Waits, L. (2013). Estimating occupancy and abundance of stream amphibians using environmental DNA from filtered water samples. Canadian Journal of Fisheries and Aquatic Sciences, 70, 1123-1130.

Pilliod, D., Golberg, C., Arkle, R., \& Waits, L. (2014). Factors influencing detection of eDNA from a stream dwelling amphibian. Molecular Ecology Resources, 14(1), 109-116.

Pollock, K., Nichols, J., Simmons, T., Farnworth, G., Bailye, L., \& Sauer, J. (2002). Large scale wildlife monitoring studies: statistical methods for design and analysis. Environmetrics, 13, 105-119.

Rothlisberger, J. \& Lodge, D. (2013). The Laurentian Great Lakes as a beachhead and a gathering place for biological invasions. Aquatic Invasions, 4, 361-374.

Shapiro, B. (2008). Engineered polymerases amplify the potential of ancient DNA. Trends in Biotechnology, 26, 285-287.

Shen, Y., Chen, X., \& Murphy, R. (2013). Assessing DNA Barcoding as a tool for species identification and data quality control. PLoS ONE, 8(2), e57125.

Shmidt, B., Kery, M., Ursenbasher, S., Hyman, O., \& Collins, J. (2013). Site occupancy models in the analysis of environmental DNA presence/absence surveys: A case study of an emergent amphibian pathogen. Methods in Ecology and Evolution, 4(7), 646-653.

Sterner, R. \& Elser, J. (2002). Ecological Stoichiometry: The biology of elements from molecules to the biosphere. Princeton: Princeton University Press.

Strayer, D. (2010). Alien species in fresh waters: ecological effects, interactions with other stressors, and prospects for the future. Freshwater biology, 55(1), 155-174.

Taberlet, P., Coissac, E., Hajibabaei, M., \& Rieseberg, L. (2012a). Environmental DNA. Molecular Ecology, 21, 1789-1793.

Taberlet, P., Coissac, E., Pompanon, F., Brochmann, C., \& Willerslev, L. (2012b). Towards next-generation biodiversity assessment using DNA metabarcoding. Molecular Ecology, 21, 2045-2050.

Takahara, T., Minamoto, T., Yamanaka, H., Hideyuki, D., \& Kawabata, Z. (2012). Estimation of fish biomass using environmental DNA. PLoS ONE, 7(4), e35868.

Takahara, T., Minamoto, T., \& Doi, H. (2013). Using environmental DNA to estimate the distribution of an invasive fish species in ponds. PLOS ONE, 8(2), e56584.

Thomsen, P., Kielgast, J., Iversen, L., Wiuf, C., Rasmussen, M., Gilbert, M., Orlando, L., \& Willerslev, E. (2012a). Monitoring endangered freshwater biodiversity using environmental DNA. Molecular Ecology, 21, 2565-2573.

Thomsen, P., Kielgast, J., Iversen, L., Moller, P., Rasmussen, M., \& Willerslev, E. (2012b). Detection of a diverse marine fauna using eDNA from seawater samples. PLOS ONE, 7(8), e41732.

Turner, C., Barnes, M., Charles, C., Xu, Y., Jones, S., Jerde, C., \& Lodge, D (2014). Particle size distribution and optimal capture of aqueous macrobial eDNA. BioRxiv doi: 10.1101/001941.

Valentini, A., Pompano, F., \& Taberlet, P. (2009). DNA barcoding for ecologists. Trends in Ecology and Evolution, 24, 110-117. 
Veldhoen, N., Ikonomou, M., \& Helbing, C. (2012). Molecular profiling of marine fauna: Integration of omics with environmental assessment of the world's oceans. Ecotoxicology and Environmental Safety, 76(1), 23-38.

Venter, J., Remington, K., Heidelberg, J., Hallpern, A., Rusch, D., Eisen, J., Wu, Du., Paulsen, I., Nelson, K., Nelson, W., Fouts, D., Levy, S., Knap, A., Lomas, M., Nealson, K., White, O., Peterson, J., Hoffman, J., Parsons, R., Baden-Tillson, H., Pfannkoch, C., Rogers, Y., \& Smith, H. (2004). Environmental genome shotgun sequencing of the Sargasso Sea. Science, 304, 66-74.

Weirbauer, M., Fucks, D., \& Peduzzi, P. (1993). Distribution of viruses and dissolved DNA along a coastal trophic gradient in the Northern Adriatic Sea. Applied Environmental Microbiology, 59(12), 4074-4082.

Wilcox, T., McKelvey, K., Young, M., Jane, S., Lowe, W., Whiteley, A., \& Schwartz, M. (2013). Robust detection of rare species using environmental DNA: The importance of primer specificity. PLOS ONE, $8(3)$, e 59520.

Willerslev, E., Hansen, A., Binladen, J., Brand, T., Gilbert, M., Shapiro, B., Bunce, M., Wiuf, C., Gilichisky, D.,
\& Cooper, A. (2003). Diverse plant and animal genetic record from Holocene and Pleistocene sediments. Science, 300, 791-795.

Willerslev, E., Capellini, A., Boomsman, W. R., \& Nielsen, M. (2007). Ancient biomolecules from deep ice cores reveals a forested Southern Greenland. Science, 317, 111-114.

Wilson, C. \& E. Wright. (2013). Using environmental DNA (eDNA) as a tool in risk-based decision making. Technical Report, Ontario Ministry of Natural Resources, Aquatic and Research Development Section. Aquatic Research Series, 2013-01.

Yoccoz, N. (2012). The future of environmental DNA in ecology. Molecular Ecology, 21, 2031-2038.

Zarzoso-Lacoste, D., Corse, E., \& Vidal, G. (2013). Improving PCR detection of prey in molecular diet studies: importance of group specific primers set selection and extraction protocol performances. Molecular Ecology Resources, 13(1), 117-127.

Zhu, B. (2006). Degradation of plasmid and plant DNA in water microcosms monitored by natural transformation of real time polymerase chain reaction (PCR). Water Research, 40, 3231-3238. 